Edubiotik: Jurnal Pendidikan, Biologi dan Terapan

ISSN 2528-679X (print), ISSN 2597-9833 (online)

Volume 4, Nomor 02, Tahun 2019, Hal. 121 - 127

Available online at:

http://ejurnal.budiutomomalang.ac.id/index.php/edubiotik

\title{
Penerapan modul biologi berorientasi problem based learning untuk meningkatkan hasil belajar kognitif mahasiswa keperawatan
}

\author{
Lisa Fradisa, Kalpana Kartika \\ STIKes Perintis Padang, Padang, Indonesia \\ E-mail: lisafradisa@gmail.com*, ananopa@gmail.com
}

\begin{tabular}{|c|c|}
\hline Informasi Artikel & ABSTRACT \\
\hline $\begin{array}{l}\text { Submit: } \\
05-08-2019 \\
\text { Diterima: } \\
21-08-2019 \\
\text { Dipublikasikan: } \\
01-09-2019\end{array}$ & $\begin{array}{l}\text { The low understanding of students in learning biology in cell communication } \\
\text { materials. One way to overcome these problems is to apply a problem-based } \\
\text { learning-oriented biology module. This study aims to determine the } \\
\text { improvement of cognitive learning outcomes of nursing students through the } \\
\text { application of problem-based learning oriented biology modules. This type of } \\
\text { research is Classroom Action Research conducted } 2 \text { cycles. The study was } \\
\text { conducted at STIKes Perintis Padang. The subjects of this study were } 28 \\
\text { nursing students. The research instrument consisted of observation sheets, } \\
\text { student cognitive learning test results, documentation and field notes. Data } \\
\text { collection is done by formative tests. Data analysis techniques using } \\
\text { descriptive analysis. The results showed that the application of problem based } \\
\text { learning oriented biology modules could improve student cognitive learning } \\
\text { outcomes with classical completeness from } 79 \% \text { to reach } 89 \% \text { and increase } \\
\text { in cognitive learning outcomes into the medium category (N-gain } 0.5) \text {. Based } \\
\text { on these results it can be concluded that the application of problem-based } \\
\text { learning-oriented biology modules can improve the cognitive learning } \\
\text { outcomes of nursing students. } \\
\text { Key words: Biology, Learning outcomes, Modules }\end{array}$ \\
\hline Penerbit & ABSTRAK \\
\hline $\begin{array}{l}\text { Program Studi } \\
\text { Pendidikan Biologi, } \\
\text { Fakultas Pendidikan } \\
\text { Ilmu Eksakta dan } \\
\text { Keolahragaan, IKIP } \\
\text { Budi Utomo, Malang, } \\
\text { Indonesia }\end{array}$ & $\begin{array}{l}\text { Rendahnya pemahaman mahasiswa dalam pembelajaran biologi pada materi } \\
\text { komunikasi sel. Salah satu cara untuk mengatasi masalah tersebut adalah } \\
\text { menerapkan modul biologi berorientasi problem based learning. Penelitian ini } \\
\text { bertujuan untuk mengetahui peningkatan hasil belajar kognitif mahasiswa } \\
\text { keperawatan melalui penerapan modul biologi berorientasi problem based } \\
\text { learning. Jenis penelitian adalah Penelitian Tindakan Kelas yang } \\
\text { dilaksanakan } 2 \text { siklus. Peneltiian dilaksanakan di STIKes Perintis Padang. } \\
\text { Subjek penelitian ini adalah mahasiswa Keperawatan tingkat satu yang } \\
\text { berjumlah } 28 \text { orang. Instrumen penelitian terdiri dari lembar observasi, tes } \\
\text { hasil belajar kognitif mahasiswa, dokumentasi dan catatan lapangan. } \\
\text { Pengambilan data dilakukan dengan tes formatif. Teknik analisis data } \\
\text { menggunakan analisis deskriptif. Hasil penelitian menunjukkan bahwa } \\
\text { penerapan modul biologi berorientasi problem based learning dapat } \\
\text { meningkatkan hasil belajar kognitif mahasiswa dengan ketuntasan klasikal } \\
\text { dari } 79 \% \text { hingga mencapai } 89 \% \text { dan peningkatan hasil belajar kognitif masuk } \\
\text { kategori sedang ( } N \text {-gain 0,5). Berdasarkan hasil penelitian tersebut } \\
\text { disimpulkan bahwa penerapan modul biologi berorientasi problem based } \\
\text { learning dapat meningkatkan hasil belajar kognitif mahasiswa keperawatan. } \\
\text { Kata kunci: Biologi, Hasil belajar, Modul }\end{array}$ \\
\hline
\end{tabular}

This Edubiotik : Jurnal Pendidikan, Biologi dan Terapan is licensed under a CC BY-SA (Creative Commons Attribution-ShareAlike 4.0 International License) 


\section{PENDAHULUAN}

Sistem Pendidikan Nasional menurut Undang-Undang RI No. 20 Tahun 2003 pasal 1 bahwa, pendidikan adalah usaha sadar dan terencana untuk mewujudkan suasana belajar dan proses pembelajaran agar peserta didik secara aktif mengembangkan potensi dirinya untuk memiliki kekuatan spritual keagamaan, pengendalian diri, kepribadian, kecerdasan, akhlak mulia, serta keterampilan yang diperlukan (Sulistiyani, 2017). Proses pendidikan yang baik tentunya akan menghasilkan manusia yang berkualitas sehingga mampu dan proaktif dalam menghadapi tantangan zaman saat ini (Sepriyaningsih, Samitra, \& Yunita, 2019). Tercapainya tujuan pembelajaran tidak lepas dari upaya dalam meningkatkan dan memperbaiki kualitas pembelajaran. Pencapaian tersebut didasarkan dari kegiatan refleksi penyelenggaraan suatu mata kuliah yang secara substantif terus dilakukan melalui program perbaikan proses, diantaranya penerapan strategi aplikatif agar mahasiswa memiliki pengetahuan sekaligus pengalaman setelah mempelajari suatu materi pembelajaran (Parmin, 2012).

Proses pembelajaran mata kuliah biologi di prodi S1 keperawatan dirancang khusus agar mahasiswa mampu memahami konsep-konsep dasar biologi yang pada gilirannya nanti dapat mengintegrasikan ilmu biologi ini dengan ilmu keperawatan lainnya. Menggunakan metode dan strategi pembelajaran yang sesuai dengan topik materi pembelajaran. Pemahan materi komunikasi sel adalah sangat penting karena akan berhubungan dengan pemahaman konsep lanjutan dalam pembelajaran biologi. Salah satu strateginya adalah dengan model problem based learning. Di dalam buku (Inovasi Pendidikan melalui problem based learning, M Taufiq Amir) dijelaskan bahwa perlu dilakukan suatu upaya yaitu dengan mengimplementasikan penerapan suatu model pembelajaran yang memungkinkan terjadinya kegiatan belajar mengajar yang kondusif. Dalam hal ini pembelajaran didesain dengan mengkonfrontasikan mahasiswa dengan masalah-masalah kontektual yang berhubungan dengan materi sehingga mahasiswa mengetahui alasan mereka belajar, mengidentifikasi dan mengumpulkan informasi dari buku sumber, serta diskusi dengan teman untuk dapat mencarikan solusi masalah yang dihadapinya (Darma, Putra, Maulina, \& Pohan, 2018).

Berdasarkan refleksi yang telah dilakukan dosen pengampu mata kuliah biologi keperawatan di STIKes perintis Padang telah teridentifikasi beberapa permasalahan yang menyebabkan hasil belajar kognitif mahasiswa dalam pembelajaran biologi belum sesuai harapan. Permasalahan yang ditemukan yaitu: pembelajaran yang dilakukan oleh dosen belum optimal. Pembelajaran masih bersifat konvensional dengan metoda ceramah. Dosen mengajar hanya menggunakan power point, sehingga proses pembelajaran masih bersifat teacher center. Tidak adanya sumber belajar seperti modul dalam pelaksanaan pembelajaran yang menyebabkan mahasiswa menjadi dominan mendengarkan dan mencatat menyebabkan kegiatan pembelajaran menjadi pasif. Hal ini juga didukung dengan hasil diskusi yang dilakukan terhadap beberapa mahasiswa bahwa dalam memperoleh informasi mahasiswa cenderung mengharapkan informasi dari dosen dan tidak tertarik membaca buku yang berkaitan dengan materi biologi. Permasalahan ini secara tidak 
langsung mempengaruhi rendahnya hasil belajar kognitif mahasiswa yang ditunjukkan setelah dilakukan evaluasi hasil belajar.

Pada kajian ini penelitian diarahkan pada aspek kognitif mahasiswa. Menurut Benjamin S. Bloom terdapat enam tingkatan penilaian ranah kognitif yaitu pengetahuan, pemahaman, penerapan, analisis, sintesis, dan evaluasi. Kedua aspek pertama disebut kognitif tingkat rendah dan keempat aspek berikutnya termasuk kognitif tingkat tinggi (Fiteriani \& Baharudin, 2018). Dalam merancang materi pembelajaran terdapat lima kategori kapabilitas yang dapat di-pelajari oleh peserta didik yaitu informasi verbal, keterampilan intelektual, strategi kognitif, sikap, dan keterampilan motorik. Kelima hal tersebut untuk selanjutnya dapat dikaji kelemahan dan kekuatan di dalam setiap pelaksanaan pembelajaran sehingga akan diperoleh analisis kasus pembelajaran yang baik (Saito, Harun, \& Kuboki, 2006). Mahasiswa harus mencapai hard dan soft skill dalam pembelajaran (Delita, Elfayetti, \& Sidauruk, 2016), kememampuan memecahkan masalah (Hariatik, Suciati, \& Sugiyarto, 2017) strategi untuk mencapai hasil belajar (Nurhayati, Saputri, \& Sari, 2015) dengan manfaat yang dapat dirasakan langsung akan sangat menarik dan bermakna (Nuswowati, Susilaningsih, Ramlawati, \& Kadarwati, 2017).

Sehubungan dengan permasalahan yang telah diuraikan maka terdapat adanya kesenjangan antara harapan dengan kenyataan yang dialami mahasiswa S1 Keperawatan di STIKes Perintis Padang dalam pembelajaran biologi. Untuk mengatasi hal tersebut alternatif yang menjadi solusi permasalahan adalah dengan menerapkan modul biologi berorientasi problem based learning. Adapun yang menjadi tujuan penelitian ini adalah untuk mengetahui peningkatan hasil belajar kognitif mahasiswa dalam pembelajaran biologi menggunakan modul berorientasi problem based learning. Mahasiswa dalam pembelajaran akan diarahkan pada strategi dan model pembelajaran dengan pendekatan ilmiah menggunakan model pembelajaran problem based learning yang sesuai dengan kebutuhan mahasiswa.

\section{METODE PENELITIAN}

Jenis penelitian yang dilakukan adalah Penelitian Tindakan Kelas (Classroom Action Research). Penelitian tindakan kelas, dilaksanakan selama 2 siklus (satu siklus 2 kali tatap muka), dengan masing-masing siklus terdiri dari 4 tahapan yaitu; perencanaan, pelaksanaan, observasi, dan refleksi (Husnul, 2009). Penelitian dilaksanakan pada semester genap tahun akademik 2018/2019, yang dimulai pada bulan Maret sampai April 2019. Materi pada penelitian ini adalah komunikasi sel. Subjek penelitian ini adalah mahasiswa keperawatan STIKes Perintis Padang tingkat 1 semester genap tahun akademik 2018/2019, yang berjumlah 28 orang. Instrumen penelitian terdiri dari lembar observasi, tes hasil belajar mahasiswa, dokumentasi dan catatan lapangan. Pengambilan data dilakukan dengan tes formatif. Teknik analisis data menggunakan analisis deskriptif dan menghitung nilai gain skor $(\mathrm{N}$ gain) untuk mengetahui peningkatan hasil belajar kognitif mahasiswa keperawatan.

Prestasi hasil siklus I, II, dan observasi awal dianalisis untuk mengetahui ketuntasan belajar siswa dan daya serap klasikal. Hal ini dilakukan dengan menganalisis nilai tes formatif menggunakan kriteria ketuntasan belajar. Tujuannya untuk mengetahui daya serap mahasiswa dimana seorang mahasiswa disebut 
tuntas belajar jika mencapai rentang nilai $\geq 71$ dan daya serap klasikal $\geq 85 \%$. Sedangkan peningkatan prestasi belajar didapat dengan membandingkan hasil prestasi pada siklus itu dengan prestasi awal atau sebelumnya (peningkatan prestasi pada siklus I dibandingkan dengan prestasi awal atau sebelum tindakan dan peningkatan prestasi pada siklus II dibandingkan dengan siklus I).

\section{HASIL PENELITIAN DAN PEMBAHASAN}

Data penelitian yang dikumpulkan pada siklus 1 berupa hasil belajar kognitif mahasiswa selama pembelajaran menggunakan modul biologi berorientasi problem based learning. Data yang diambil adalah hasil pembelajaran tiap akhir siklus. Masing-masing tindakan itu memaparkan tentang: Hasil belajar kognitif mahasiswa dan analisis ketuntasan belajar klasikal tiap siklus. Selengkapnya hasil penelitian yang telah diperoleh pada siklus 1 disajikan pada Tabel 1 berikut.

Tabel 1. Persentase ketuntasan Hasil Tes Siklus I

\begin{tabular}{ccccc}
\hline Nilai & Jumlah Mahasiswa & Persentase & Akumulasi & Ketuntasan \\
\hline $86-100$ & 1 & $4 \%$ & $4 \%$ & \\
$81-85$ & 16 & $57 \%$ & $57 \%$ & 22 mahasiswa tuntas \\
$71-80$ & 5 & $18 \%$ & $18 \%$ & \\
$66-70$ & 6 & $21 \%$ & - & \\
$61-65$ & - & $0 \%$ & - & 6 mahasiswa tidak tuntas \\
$<61$ & - & $0 \%$ & - & \\
Total & $\mathbf{2 8}$ & $\mathbf{1 0 0 \%}$ & $\mathbf{7 9 \%}$ & \\
\hline
\end{tabular}

Berdasarkan data pada Tabel 1 di atas, diketahui ketuntasan belajar klasikal siklus I mencapai $79 \%$. Secara umum dapat disimpulkan hasil penelitian tindakan kelas siklus I termasuk 'Baik' karena 79\% mahasiswa tuntas belajar, dimana 22 mahasiswa yang tuntas dan 6 mahasiswa tidak tuntas. Namun persentase tersebut belum mampu mencapai target ketuntasan, sedangkan target ketuntasan klasikal minimal yang $80 \%$ mahasiswa tuntas belajar, oleh karena itu peneliti melanjutkan tindakan pada siklus II. Adapun rincian penyajian hasil penelitian siklus II seperti Tabel 2 berikut.

Tabel 2. Persentase ketuntasan Hasil Tes Siklus II

\begin{tabular}{ccccc}
\hline Nilai & Jumlah Mahasiswa & Persentase & Akumulasi & Ketuntasan \\
\hline $86-100$ & 2 & $7 \%$ & $7 \%$ & \\
$81-85$ & 21 & $75 \%$ & $75 \%$ & 25 mahasiswa tuntas \\
$71-80$ & 2 & $7 \%$ & $7 \%$ & \\
$66-70$ & 3 & $11 \%$ & - & \\
$61-65$ & - & - & - & 3 mahasiswa tidak tuntas \\
$<61$ & - & $\mathbf{1 0 0 \%}$ & $\mathbf{8 9} \%$ & \\
Total & $\mathbf{2 8}$ & & & \\
\hline
\end{tabular}

Berdasarkan data yang tercantum pada Tabel 2 di atas, diketahui ketuntasan belajar klasikal siklus II mencapai $89 \%$. Dengan jumlah 25 mahasiswa yang tuntas dan tidak tuntas berkurang menjadi 3 mahasiswa. Selanjutnya nilai gain skor $(N$ gain) diketahui sebesar $0,5(0,7>g \geq 0,3)$ yang berarti peningkatan hasil belajar kognitif mahasiswa keperawatan masuk kedalam kategori sedang.

Dari data hasil penelitian yang disajikan terlihat bahwa hasil belajar mahasiswa meningkat dan dapat disimpulkan penelitian ini berhasil mencapai tujuan. 
Pelaksanaan tindakan siklus II pada mahasiswa S1 Keperawatan STIKes Perintis Padang tingkat satu, tahun akademik 2018/2019 telah berhasil di mana persentase ketuntasan belajar klasikal mencapai $89 \%$. Persentase ketuntasan ini telah melewati standar ketuntasan klasikal minimal $80 \%$ yang telah ditetapkan. Dengan telah tercapainya hasil tersebut maka penelitian ini dihentikan. Peningkatan ketuntasan belajar mahasiswa pada siklus II antara lain disebabkan oleh meningkatnya rasa ingin tahu mahasiswa, minat, serta keaktifan mahasiswa dalam proses pembelajaran, dimana jumlah mahasiswa yang aktif dalam perkuliahan semakin bertambah pada setiap tatap muka. Mulai dari pertemuan di siklus I sampai siklus II. Mulai dari memahami teori, pemecahan masalah yang disajikan pada bab pendahuluan yang disajikan pada modul, dan pemahaman konsep dasar materi. Terlihat adanya perubahan antusias dalam mengikuti proses pembelajaran dengan baik. Selama pelaksanaan pembelajaran pada siklus I dan siklus II dari hasil pengamatan dapat diketahui telah terjadi perubahan pada mahasiswa ke arah yang lebih baik hal ini sejalan dengan tujuan penelitian Rusydi (2017) dan Safriadi, A., S., \& Nurmaliah (2013) dengan penerapan problem based learning dapat meningkatkan kreativitas mahasiswa. Kemudian penelitian Erinda, Indriwat, \& Sulasmi (2018) dan Riyanto \& Susilawati, (2019) menunjukkan bahwa penerapan media yang dikembangkan mampu meningkatkan aktivitas belajar mahasiswa sehingga pembelajaran di kelas akan lebih efektif, efisien dan dapat meningkatkan hasil belajar kognitif mahasiswa. Perbandingan hasil penelitian ini dengan peneltian sebelumnya adalah pada penelitian ini penerapkan modul biologi berorientasi problem based learning pada materi komunikasi antar sel. Sedangkan penelitian terdahulu seperti penelitian Riyanto \& Susilawati, (2019) lebih terfokus pada penerapan media pembelajaran berupa media aurora animasi 3D maker. Selain itu, penelitian yang dilakukan oleh Erinda, Indriwat, \& Sulasmi (2018) yakni modul yang diterapkan adalah modul yang memuat materi keanekaragaman tumbuhan home science process skill berbasis inkuiri terbimbing bermuatan karakter.

\section{SIMPULAN DAN SARAN}

Berdasarkan hasil penelitian dan pembahasan dapat disimpulkan bahwa penerapan modul biologi berorientasi problem based learning dapat meningkatkan hasil belajar kognitif mahasiswa keperawatan STIKes Perintis Padang. Hal ini terlihat dari peningkatan hasil belajar kognitif mahasiswa dari siklus I sebesar $79 \%$ menjadi sebesar $89 \%$ pada siklus II dan peningkatan hasil belajar kognitif masuk kedalam kategori sedang $(\mathrm{N}$-gain 0,5$)$. Perlu penelitian lebih lanjut dengan metode penelitian yang berbeda untuk mengetahui efektivitas atau pengaruh modul biologi berorientasi problem based learning sehingga modul tersebut benar-benar layak untuk digunakan dalam pembelajaran di STIKes Perintis Padang.

\section{UCAPAN TERIMA KASIH}

Ucapan terima kasih disampaikan kepada semua pihak yang telah mendukung pelaksanaan kegiatan penelitian sehingga penelitian dapat berjalan dengan baik. 


\section{RUJUKAN}

Darma, E., Putra, S., Maulina, J., \& Pohan, L. A. (2018). Penerapan Model Pembelajaran Problem Based Learning Menggunakan Handout dan Modul pada Materi Stoikiometri Larutan di SMA Nurul Amaliyah Deli Serdang. Journal of Chemistry, Education, and Science, 2(1), 1-13. Retrieved from https://jurnal.uisu.ac.id/index.php/CHEDS/article/view/692

Delita, F., Elfayetti, \& Sidauruk, T. (2016). Peningkatan soft skills dan hard skills mahasiswa melalui Project-based learning pada mata kuliah Perencanaan pembelajaran geografi. Jurnal Geografi, 8(2), 124-135. Retrieved from https://jurnal.unimed.ac.id/2012/index.php/geo/article/view/5776

Erinda, L., Indriwat, S. E., \& Sulasmi, E. S. (2018). Pengembangan Modul Keanekaragaman Tumbuhan Home Science Process Skill Berbasis Inkuiri Terbimbing Bermuatan Karakter Untuk Meningkatkan Hasil Belajar Dan Keterampilan Proses di MAN 1 MalangPengembangan Modul Keanekaragaman Tumbuhan. Jurnal Pendidikan Biologi, 9(2), 64-70. https://doi.org/ 10.17977/jpb.v9i2.5302

Fiteriani, I., \& Baharudin. (2018). Analisis Perbedaan Hasil Belajar Kognitif Menggunakan Metode Pembelajaran Kooperatif yang Berkombinasi pada Materi IPA di MIN Bandar Lampung. Terampil Jurnal Pendidikan Dan Pembelajaran Dasar, 4(2), 1-30. Retrieved from http://ejournal.radenintan.ac.id/index.php/ terampil/article/view/2224

Hariatik, Suciati, \& Sugiyarto. (2017). Pembelajaran Biologi Model Problem Based Learning (PBL) disertai Dialog Socrates (DS) Terhadap Hasil Belajar ditinjau dari Kemampuan Memecahkan Masalah Kelas X. Jurnal Pendidikan Biologi, 8(2), 45-51. Retrieved from http://journal2.um.ac.id/index.php/jpb/article/view/2277

Husnul, H. S. Yuyun Husnul. (2009). Penelitian Tindakan Kelas. Surabaya: Bayumedia.

Nurhayati, Saputri, D. F., \& Sari, I. N. (2015). Efektivitas penggunaan modul fisika berbasis inkuiri terhadap hasil belajar dan kemandirian belajar mahasiswa 1,2,3. Jurnal Pendidikan Informatika Dan Sains, 4(2), 247-258. Retrieved from http://journal.ikippgriptk.ac.id/index.php/saintek/article/view/74

Nuswowati, M., Susilaningsih, E., Ramlawati, \& Kadarwati, S. (2017). Implementation of problem-based learning with green chemistry vision to improve creative thinking skill and students' creative actions. Jurnal Pendidikan IPA Indonesia, 6(2), 221-228. https://doi.org/10.15294/jpii.v6i2.9467

Parmin. (2012). Penerapan Critical Review Artikel Pembelajaran Ipa Untuk Meningkatkan Kemampuan Mahasiswa Dalam Menyusun Proposal Skripsi. Jurnal Pendidikan IPA Indonesia, 1(2), 183-191. Retrieved from http://journal.unnes.ac.id/index.php/jpii

Riyanto, R., \& Susilawati, L. (2019). Penerapan Media Aurora Animasi 3D Maker Untuk Meningkatkan Hasil Belajar Kognitif Mahasiswa Biologi Ikip Budi Utomo Malang. Edubiotik: Jurnal Pendidikan, Biologi Dan Terapan, 4(01), 52-57. https://doi.org/10.33503/ebio.v4i01.438

Rusydi, R. (2017). Pembelajaran Berbasis Masalah (PBM) Pada Materi Termodinamika Untuk Meningkatkan Kemampuan Kognitif Dan Kemampuan Kreatif (Kreativitas) Mahasiswa Ftk Uin Ar-Raniry Banda Aceh. Jurnal IPA \& Pembelajaran IPA, 1(2), 192-202. https://doi.org/10.24815/jipi.v1i2.9694

Safriadi, A, S, M. A., \& Nurmaliah, C. (2013). Upaya Peningkatan Belajar Kognitif Melalui Model Problem Based Learning. 1(2), 87-92. Retrieved from http://jurnal.ar-raniry.ac.id/index.php/biotik/article/view/218

Saito, E., Harun, I., \& Kuboki, I. (2006). Indonesian lesson study in practice : case 
study of Indonesian mathematics. Journal of In-Service Education, 32(2). https://doi.org/10.1080/13674580600650872

Sepriyaningsih, Samitra, D., \& Yunita, M. (2019). Pengaruh Model Team Assisted Individualization (TAI) Terhadap Hasil Belajar Biologi Siswa Kelas X SMA Negeri 8 Lubuk Linggau Pendidikan Biologi , STKIP PGRI Lubuklinggau. Jurnal Pendidikan Biologi, 4(1), 29-34. https://doi.org/10.31932/jpbio.v4i1.368

Sulistiyani. (2017). Pengaruh Modul Pembelajaran Berbasis Problem Based Learning Terhadap Hasil Belajar. SAP, 2(2), 140-145. Retrieved from https://journal.Ippmunindra.ac.id/index.php/SAP/article/view/2086 